\title{
Population Trends of Gulls and Arctic Terns Nesting in the Belcher Islands, Nunavut
}

\author{
H. GRANT GILCHRIST ${ }^{1}$ and GREGORY J. ROBERTSON ${ }^{2}$
}

\author{
(Received 29 April 1998; accepted in revised form 18 April 1999)
}

\begin{abstract}
Little information exists on the population trends of gulls and terns nesting in the Arctic. In 1997, we surveyed the number of glaucous gull (Larus hyperboreus), herring gull (Larus argentatus), and arctic tern (Sterna paradisaea) nests on the Belcher Islands $\left(56^{\circ} 00^{\prime}-57^{\circ} 30^{\prime} \mathrm{N}, 79^{\circ} 30^{\prime}-80^{\circ} 00^{\prime} \mathrm{W}\right)$. We compared our results with the mean number of nests per island counted in the Belcher Islands in the late 1980s using the same survey methods. The mean number of gull nests per island had declined in all five archipelagos surveyed, and the decline was significant in three regions. The number of arctic tern nests had also declined in all three regions where they were originally present, although this decline was significant in only one region. The causes of these apparent declines are unknown. Adult mortality or emigration of gulls from the area may have occurred in response to changes in polynya formation during recent winters, which restricted access to marine food sources. Reproductive success of gulls may also be low in response to the recent $75 \%$ decline in common eiders nesting in the Belcher Islands. Eider eggs and ducklings are an important food source for gulls during the breeding season. The decline of nesting arctic terns may reflect either winter mortality of tern populations caused by unknown factors or emigration out of the Belcher Islands in response to regional egging and disturbance by local residents.
\end{abstract}

Key words: arctic tern, Sterna paradisaea, Belcher Islands, glaucous gull, Larus hyperboreus, herring gull, Larus argentatus, polynyas, population trends

RÉSUMÉ. Il existe peu de renseignements sur les tendances dans les changements de population des mouettes et sternes qui nichent dans l'Arctique. En 1997, on a établi un relevé des nids du goéland bourgmestre (Larus hyperboreus), du goéland argenté (Larus argentatus) et de la sterne arctique (Sterna paradisaea) dans les îles Belcher $\left(56^{\circ} 00^{\prime}-57^{\circ} 30^{\prime}\right.$ de latit. N., $79^{\circ} 30^{\prime}-80^{\circ} 00^{\prime}$ de longit. O.). Nous avons comparé nos résultats avec le nombre moyen de nids par île comptés dans les îles Belcher à la fin des années 1980, en employant les mêmes méthodes de relevés. Le nombre moyen de nids de goélands par île a baissé dans les cinq archipels étudiés, et la baisse s'est révélée importante dans trois régions. Le nombre de nids de sternes arctiques avait également baissé dans les trois régions où elles étaient présentes à l'origine, bien que ce déclin ne fût important que dans une seule région. On ne connaît pas les causes de ces baisses apparentes. La mortalité adulte ou l'émigration des goélands de cette zone aurait pu se produire en réponse aux changements survenus dans la formation de la polynie au cours des derniers hivers - changements qui auraient limité l'accès aux aliments venant de la mer. Le succès de reproduction du goéland pourrait aussi être bas suite au déclin récent de 75 p. cent chez l'eider à duvet qui niche dans les îles Belcher. Les oeufs d'eider et les oisons constituent une importante source alimentaire pour les goélands durant la saison de nidification. Le déclin de la sterne arctique peut être un symptôme soit de la mortalité hivernale des population de sternes dont la cause reste inconnue, soit d'une émigration des îles Belcher en réponse à la collecte des oeufs et à la perturbation dont sont responsables les habitants de la région.

Mots clés: sterne arctique, Sterna paradisaea, îles Belcher, goéland bourgmestre, Larus hyperboreus, goéland argenté, Larus argentatus, polynies, tendances dans les changements de population

Traduit pour la revue Arctic par Nésida Loyer.

\section{INTRODUCTION}

Populations of many gull species have increased dramatically during the last century (Blokpoel and Tessier, 1986). Expansions in range have accompanied population increases for several species. For example, great blackbacked gulls (L. marinus) have increased in number and are ranging further south in Atlantic Canada and New England (Drury, 1973, 1974; Ewins et al., 1992). Gull populations have apparently responded to increased levels of food from garbage waste (Spaans, 1971) and fisheries offal (Furness et al., 1992; Howes and Montevecchi, 1993). These artificial food sources may enhance reproductive success during the breeding season and overwinter survival of both young and adults (Sibly and McCleery, 1983; Pierotti and Annett, 1991; Pons, 1992). The population dynamics of gulls are of interest because some gull species depredate the nests of other birds. Predation by gulls may increase when artificial food sources are suddenly removed, forcing gulls to prey intensively on naturally

\footnotetext{
${ }^{1}$ Canadian Wildlife Service, Environment Canada, Suite 301, 5204 50th Avenue, Yellowknife, Northwest Territories X1A 1E2, Canada; grant.gilchrist@ec.gc.ca

${ }^{2}$ Canadian Wildlife Service, Environment Canada, 6 Bruce Street, Mount Pearl, Newfoundland A1N4T3, Canada; greg.robertson@ ec.gc.ca (C) The Arctic Institute of North America
} 
occurring prey (Pons, 1992; Regehr and Montevecchi, 1997; Gilchrist, 1998).

Whereas gull numbers have generally increased, tern populations have tended to decline (Nisbet, 1973; Drury, 1973, 1974; Courtney and Blokpoel, 1983; Chapdelaine, 1995; Spendelow et al., 1995). In fact, one factor causing declines in tern populations is that terns are often displaced from their nesting areas by increasing populations of breeding gulls (Kress, 1983; Morris et al., 1992). Disturbance, loss of nesting habitat to human development, and a reduction in their food supply caused by commercial fisheries have also been implicated in the decline of tern populations in North America (Morris and Hunter, 1976; Morris et al., 1980).

In contrast to populations breeding at southern latitudes, arctic species are unlikely to have food waste as a significant factor during the breeding season (except perhaps the ivory gull; Haney and MacDonald, 1995). Therefore, gulls and terns nesting in the North should rely on natural prey items while breeding, and perhaps are less affected by human development. However, there is very little information on the population trends of gulls and terns nesting in the Arctic.

We counted nests of glaucous gulls (Larus hyperboreus), herring gulls (L. argentatus), and arctic terns (Sterna paradisaea) breeding in the Belcher Islands in 1997. Nests were counted in the Belcher Islands in the 1980s, using the same survey methods (Fleming and McDonald, 1987; Nakashima and Murray, 1988; McDonald and Fleming, 1990). This paper compares the 1980s counts of gull and tern nests to our 1997 counts and explores possible reasons for the differences.

\section{METHODS}

\section{Surveys}

The Belcher Islands $\left(56^{\circ} 00^{\prime}\right.$ to $57^{\circ} 30^{\prime} \mathrm{N}, 79^{\circ} 30^{\prime}$ to $80^{\circ} 00^{\prime} \mathrm{W}$ ) are a complex of island archipelagos in southeastern Hudson Bay. Islands range in size from $1 \mathrm{~m}^{2}$ to $>1000 \mathrm{~km}^{2}$. This region and its avifauna are well described by Freeman (1970) and Manning (1976). Five archipelagos were chosen for a study between 1985 and 1989 to assess common eider nesting densities (Fleming and McDonald, 1987; Nakashima and Murray, 1988; McDonald and Fleming, 1990). In these studies (Fig. 1), all islands less than 500 ha were numbered within each region, and $50 \%$ of these islands were randomly selected for survey. We attempted to return to these selected islands in 1997. In some cases, however, logistical constraints prevented us from doing so. Occasionally an island was not clearly delineated on the maps or may have been attached to the mainland at low tide. Sample sizes thus vary between the two surveys. All surveys were conducted in early July.

Islands were surveyed by one of two methods. Small islands $(<0.05$ ha) could be completely examined from a boat. If there was any evidence of nesting birds, we landed to examine the island on foot. During surveys, crews of three to six field workers walked across islands $10 \mathrm{~m}$ apart from each other. If the island could not be surveyed in one sweep, the crew member at the outside of the line would mark the extent of the first pass with rocks or sticks. The crew would then turn around and return, counting only nests on the opposite side of the previously marked line. In this manner, islands were completely surveyed with little risk of missing nests or counting nests more than once.

Gull nests were easy to locate because there was little vegetation and their large nest mounds usually stood out prominently. As in previous surveys, no attempt was made to distinguish between glaucous gull and herring gull nests, as the eggs of these species could not be distinguished reliably. Islands that supported tern colonies were obvious because large numbers of terns circled above these islands as we approached. On islands where terns were present, we intensified the survey and walked closer together (ca. $5 \mathrm{~m}$ apart). Undoubtedly, some tern nests were still missed by the survey, but we assume that the numbers of nests missed by crews in the 1980s and in 1997 should be the same because survey techniques were identical. In fact, many of the same individuals participated in both surveys.

When a nest was found, its contents were called out to one crew member, who recorded the information. For each nest, we recorded the species, the number of eggs, and the status of the nest. Nest status was recorded as either (1) incubating, (2) pipping, (3) all eggs hatched, or (4) partially depredated or completely destroyed.

\section{Statistical Analysis: Constraints Imposed by Historical Data}

Historical data for gulls and terns were extracted from the following studies: Nakashima and Murray (1988), for surveys of the Sleeper Islands, Laddie Islands and Split Islands (1985 season); Fleming and McDonald (1987), for the South Flaherty Islands (1987 season); and, McDonald and Fleming (1990), for South Churchill Sound (1988 season). Unfortunately, only summaries of mean nests per island for each region were available to make comparisons with 1997 data (originally presented with standard error and island sample size). Our ability to detect differences in the nests per island of these species was low, and resulted in a conservative test for differences in the number of nests found. This is especially so for arctic terns because of the high variance in the number of nests counted per island. Therefore, we used a modified t-test (two-tailed) that allowed for unequal variances and sample sizes (Zar, 1984), because we did not want to assume that the two samples had equal variances. However, even with unequal variances and skewed distributions, t-tests are reasonably robust and are as informative as their nonparametric counterparts, such as the Wilcoxon matched-pairs signed-ranks test (Stewart-Oaten, 1995). Clearly, island-by-island 


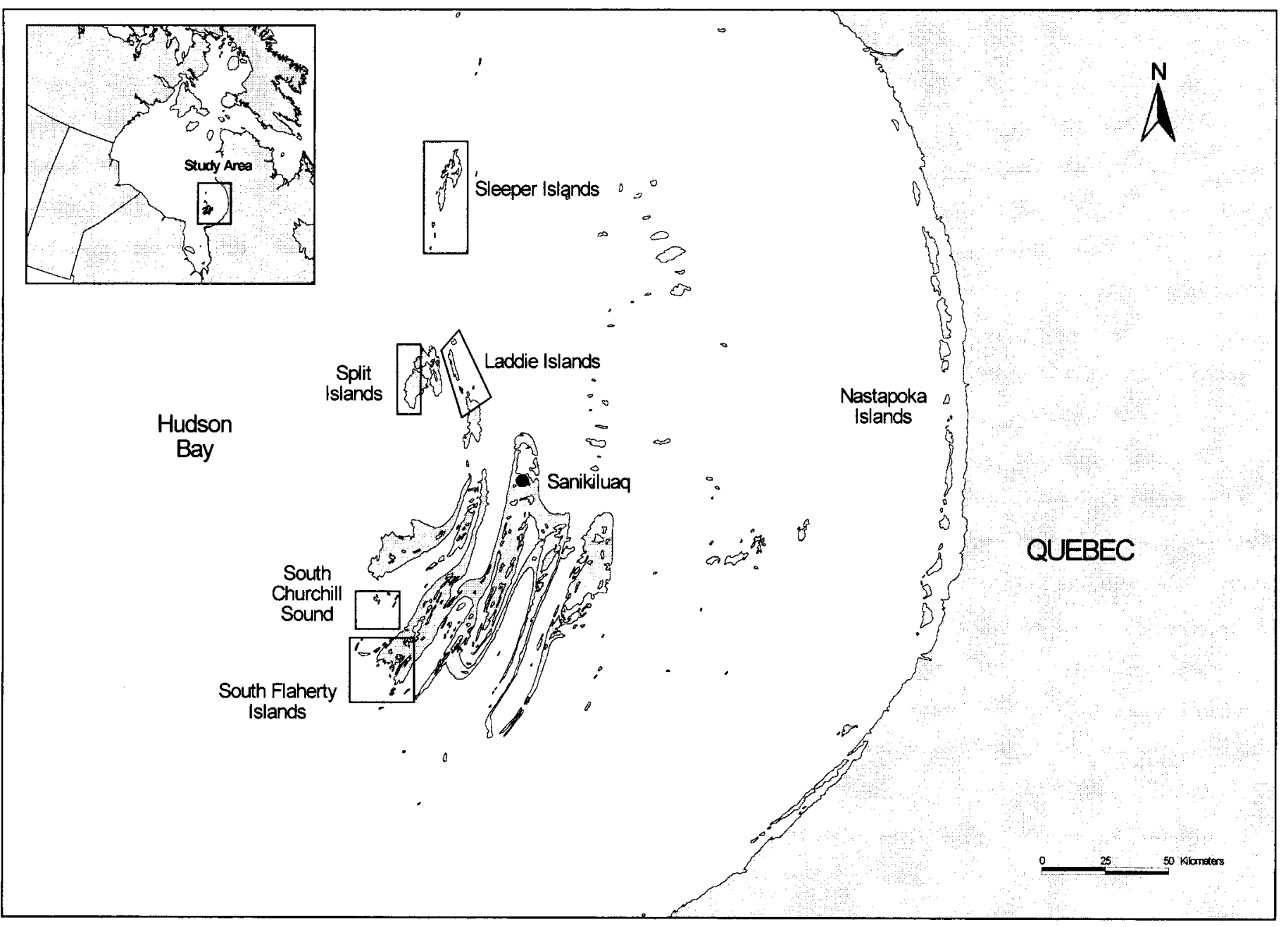

FIG. 1. Location of the study area in the Belcher Islands, Hudson Bay, Nunavut. Rectangles show the five areas surveyed in the 1980 s and resurveyed in 1997.

comparisons that recorded gains and losses between the two study periods would have been a much more powerful test. We were able to make this comparison with common eider data (Robertson and Gilchrist, 1998).

In some instances, we could extract nest information about specific islands, typically those that supported large numbers of gull and tern nests and were specifically highlighted in the original reports. These data enabled comparisons between individual islands (one island for gulls, and four islands for arctic terns).

\section{RESULTS}

Gulls -1997

In all, 208 nests were found on 431 islands, for a nest density of $0.5( \pm 2.2 \mathrm{SE})$ nests per island (Table 1). The highest density, 1.7 ( \pm 5.7 SE) nests per island, found in South Churchill Sound, was due to a relatively large colony of 28 gulls found on one island. The Split and Laddie island groups had the lowest density: only 16 nests were found on 144 islands. Gull nests were also spread out over a greater number of islands in South Churchill Sound (22.2\% of islands) than in the Laddie and Split Islands (5 to $8 \%$ of islands). Most nests were found while their eggs were still being incubated, and the mean clutch size of nests with eggs was just over two eggs (2.2 eggs/nest, $\pm 0.7 \mathrm{SE})$.

\section{Terns -1997}

Tern nests were found only in the three northern regions of the study area (Table 2). The Sleeper Islands group supported the largest number of nests $(79 \%, 213$ of total 270 islands). The distribution of tern nests was highly clumped; most nests were found in a few large colonies. All nests were found while they were being incubated, and the mean clutch size was $1.6 \pm 0.5$ eggs per nest.

\section{Comparisons between 1980s and 1997}

The mean number of gulls nesting per island in the study region has declined by $50 \%$ (Table 3 ). All five regions showed a decline in gull nest density since the 1980s (Table 3). In three regions, and overall, this decline was 
TABLE 1. Summary statistics for large gulls (glaucous gull and herring gull combined) nesting in the Belcher Islands in 1997.

\begin{tabular}{|c|c|c|c|c|c|c|}
\hline & South Flaherty Islands & South Churchill Sound & Sleeper Islands & Split Islands & Laddie Islands & Total \\
\hline Dates surveyed & $3-6$ July & $7-8$ July & $10-13$ July & 20 July & $22-23$ July & 3-23 July \\
\hline Number of islands surveyed & 153 & 27 & 107 & 62 & 82 & 431 \\
\hline Number of gull nests & 85 & 45 & 62 & 10 & 6 & 208 \\
\hline Number of nests/island (range) & $0.6 \pm 2.1(0-17)$ & $1.7 \pm 5.7(0-28)$ & $0.6 \pm 1.9(0-12)$ & $0.2 \pm 0.7(0-5)$ & $0.1 \pm 0.3(0-2)$ & $0.5 \pm 2.2(0-28)$ \\
\hline Number of islands with nests & $31(20.2 \%)$ & $6(22.2 \%)$ & $13(12.1 \%)$ & $5(8.0 \%)$ & $4(4.9 \%)$ & $59(13.7 \%)$ \\
\hline (1) Incubating & 91.8 & 100 & 67.7 & 60.0 & 66.7 & 84.1 \\
\hline (2) Hatching & 4.7 & 0.0 & 16.1 & 40.0 & 33.3 & 9.6 \\
\hline (3) Hatched & 3.5 & 0.0 & 9.7 & 0.0 & 0.0 & 4.3 \\
\hline (4) Destroyed & 0.0 & 0.0 & 6.5 & 0.0 & 0.0 & 1.9 \\
\hline Mean clutch size ${ }^{a}$ (sample size) & $2.45 \pm 0.60(78)$ & $1.84 \pm 0.71(45)$ & $2.19 \pm 0.80(42)$ & $2.17 \pm 0.75(6)$ & $1.75 \pm 0.50$ & $2.21 \pm 0.72(175)$ \\
\hline
\end{tabular}

${ }^{a}$ Only incubating nests were used to calculate clutch size.

TABLE 2. Summary statistics for arctic terns nesting in the Belcher Islands in 1997.

\begin{tabular}{|c|c|c|c|c|c|c|}
\hline & outh Flaherty Islands & South Churchill Sound & Sleeper Islands & Split Islands & Laddie Islands & Total \\
\hline Dates surveyed & 3-6 July & $7-8$ July & 10-13 July & 20 July & 22-23 July & $3-23$ July \\
\hline Number of islands surveyed & 153 & 27 & 107 & 62 & 82 & 431 \\
\hline Number of tern nests & 0 & 0 & 213 & 54 & 3 & 270 \\
\hline Number of nests/island (range) & - & - & $2.0 \pm 14.7(0-149)$ & $0.9 \pm 6.0(0-47)$ & $0.03 \pm 0.25(0-2)$ & $0.6 \pm 7.7(0-149)$ \\
\hline Number of islands with nests & 0 & 0 & $13(12.1 \%)$ & $4(6.5 \%)$ & $2(2.5 \%)$ & $19(4.4 \%)$ \\
\hline \multicolumn{7}{|l|}{$\%$ of nests in status } \\
\hline (1) Incubating & - & - & 100 & 100 & 100 & 100 \\
\hline (2) Hatching & - & - & 0 & 0 & 0 & 0 \\
\hline (3) Hatched & - & - & 0 & 0 & 0 & 0 \\
\hline (4) Destroyed & - & - & 0 & 0 & 0 & 0 \\
\hline Mean clutch size (sample size) & - & - & $1.61 \pm 0.50(213)$ & $1.79 \pm 0.49(54)$ & $1.33 \pm 0.58(3)$ & $1.64 \pm 0.51(270)$ \\
\hline
\end{tabular}

${ }^{a}$ Only incubating nests were used to calculate clutch size.

significant (Table 3). Since the number of islands in the South Churchill Sound region is small, we were able to return to all 27 islands surveyed in 1988. In 1988, there were 87 gull nests in the region; in 1997, only 45 nests were found (-48.3\% change). In 1988, the highest number of nests found on one island was 46; in 1997, only 28 nests were found on the same island ( $-39.1 \%$ change).

In all three regions, and overall, there was a decline in the number of tern nests found (Table 4). However, this decline was significant only in the Laddie Island region. In the Sleeper Island region, the largest number of tern nests found on one island in 1985 was 283, while in 1997 only 29 nests were found on this island (-89.8\% change). In 1985 , another island in the Split Island group supported a colony of 79 tern nests, but only 47 nests were found on this island in 1997 (-40.5\% change). In 1985 in the Laddie Islands, the two islands with the highest numbers of nesting terns had 31 and 26 nests on them respectively; in 1997, no tern nests were found on either island.

\section{DISCUSSION}

\section{Interpretation of Survey Results}

In the Belcher Islands, common eiders, gulls, and terns all nest on offshore islands that are inaccessible to mammalian predators. They may even nest in association with one another (Kistchinski and Flint, 1974; Götmark and Åhlund, 1988; Robertson and Gilchrist, 1998). Thus, surveys designed to assess the nesting density of one of these species should reliably assess all three (Komdeur et al., 1992). The nesting chronologies of eiders and large gulls in the Belcher Islands are similar, so counts conducted in early July should effectively survey both eiders and gulls. Indeed, in 1997 most gull and eider nests were counted while eggs were being incubated (Robertson and Gilchrist, 1998; Table 1, this study). Terns breed later than gulls and eiders, so some late nesters may not have begun to lay their clutches. However, it appeared that most terns had laid their eggs, as shown by the normal clutch size information we obtained (Table 2). As surveys were carried out at the same time each year, such late nesters would have been missed in both surveys, and no bias would result regarding population trends.

Despite low statistical power, we found that the numbers of gull and tern nests found in the Belcher Islands declined between the two surveys. There are several possible reasons for this, which are not mutually exclusive: 1) gulls and terns may have moved to other islands in the Belcher group, which we did not survey in 1997; 2) extensive nonbreeding by gulls and terns in the region may have occurred in 1997;3) birds that were resident and breeding in the 1980s may have emigrated out of the 
TABLE 3. Number of gull nests per island in the Belcher Islands, Nunavut in the 1980s and in 1997.

\begin{tabular}{lrrrrrr}
\hline \hline & \multicolumn{3}{c}{ Nests per Island } & & \\
\cline { 2 - 5 } & \multicolumn{2}{c}{$1980 \mathrm{~s}$} & \multicolumn{2}{c}{1997} & & $p$ \\
\hline South Flaherty Islands & $1.04 \pm 2.6$ & & & & \\
South Churchill Sound & $3.20 \pm 9.3$ & $(27)$ & $0.6 \pm 2.1$ & $(153)$ & 2.12 & 0.017 \\
Sleeper Islands & $0.80 \pm 2.9$ & $(174)$ & $0.6 \pm 1.9$ & $(107)$ & 0.85 & 0.200 \\
Split Islands & $0.70 \pm 2.3$ & $(56)$ & $0.2 \pm 0.7$ & $(62)$ & 2.08 & 0.020 \\
Laddie Islands & $0.70 \pm 1.3$ & $(78)$ & $0.1 \pm 0.3$ & $(82)$ & 5.22 & 0.0001 \\
Total & $1.00 \pm 3.3$ & $(467)$ & $0.5 \pm 2.2$ & $(431)$ & 3.51 & 0.0002 \\
\hline \hline
\end{tabular}

Belcher Islands to nest elsewhere; and 4) fewer adult gulls and terns may have been alive in the local population. Survey results may be wrongly interpreted as population declines if birds disperse from large colonies and establish small colonies that are difficult to find. However, our surveys covered up to $50 \%$ of randomly selected islands in five study regions. Thus, it is unlikely that we missed a sufficient number of islands with high nesting densities to account for the decline. Further, we found that the number of gulls and terns declined in all regions surveyed, and that there was no obvious shift in their distribution between regions.

In 1997, weather and ice conditions were also favorable. Nesting islands and adjacent waters were free of ice early in June, and both gulls and terns nested relatively early. Among gulls, very few empty nests were found on islands, and mean clutch sizes were well within the norm for the species (Table 1; Pierotti and Good, 1994). Further, the number of gulls flying above islands (recorded as pairs) generally matched the numbers of nests we found. These observations were not difficult to make because of the small numbers of gulls and nests we observed on each island (Table 1). Our findings suggest that few nonbreeding pairs were present on the islands surveyed in 1997. However, we cannot discount the possibility that we failed to detect nonbreeding gulls and terns occurring elsewhere in the Belcher Islands (e.g., foraging at sea).

It appears that 1997 was a good breeding year for both gulls and terns in the Belcher Islands. We infer that the reduction in the number of nesting females was due to a real numerical decline in the local breeding population, rather than to redistribution of nesting birds or extensive nonbreeding by females.

\section{Population Trends of Gulls}

The number of gull nests found in the Belcher Islands was about half the number counted in the 1980s. Populations of glaucous gulls nesting in association with thick-billed murres on Coats Island and the Digges Islands in northern Hudson Bay have remained stable for the last 15 years (Gaston and Gilchrist, unpublished data). This fact suggests that the declines in the number of gulls nesting in the Belcher Islands have occurred in response to local conditions.

The nesting population of gulls may have declined in response to the $75 \%$ decline in the common eider population
TABLE 4. Number of arctic tern nests per island in the Belcher Islands, Nunavut in the 1980s and in 1997.

\begin{tabular}{|c|c|c|c|c|c|}
\hline & \multicolumn{3}{|c|}{ Nests per Island } & \multirow[b]{2}{*}{$t$} & \multirow[b]{2}{*}{$p$} \\
\hline & $1980 \mathrm{~s}$ & 1997 & & & \\
\hline South Flaherty Islands & 5 & 0 & & - & - \\
\hline South Churchill Sound & 0 & 0 & & - & - \\
\hline Sleeper Islands & $4.3 \pm 26.0(174)$ & $2.0 \pm 14.7$ & $(107)$ & 1.00 & 0.158 \\
\hline Split Islands & $1.4 \pm 10.6$ & $0.9 \pm 6.0$ & $(82)$ & 0.47 & 0.312 \\
\hline Laddie Islands & $1.4 \pm 5.2$ & $0.03 \pm 0.25$ & $(62)$ & 2.64 & 0.005 \\
\hline Total & $3.0 \pm 20.4(308)$ & $0.6 \pm 7.7$ & $(251)$ & 1.91 & 0.057 \\
\hline
\end{tabular}

nesting in the Belcher Islands (Robertson and Gilchrist, 1998). During the breeding season, gulls often prey upon eider eggs and chicks (Munro and Bédard, 1977; Swennen, 1989; Mehlum, 1991; Robertson and Cooke, 1993) and steal food items brought to the surface by foraging adult eiders (Schenkeveld and Ydenberg, 1985). A decline in these food resources may have resulted in the starvation of chicks during the summer. However, we suggest that failed reproduction is insufficient to explain the large and rapid decline of nesting gulls between the two survey periods. Perhaps over time adult gulls emigrated out of the Belcher Islands to nest elsewhere in response to failed reproduction.

Higher adult mortality and emigration rates of gulls may also have occurred in response to changing sea ice conditions in the Belcher Islands. Polynyas around the Belcher Islands that normally remain open all winter froze in the early 1990s (McDonald et al., 1997). These freezing events apparently prevented access to marine food resources and resulted in mass die-offs of marine birds, particularly eiders, in the region (McDonald et al., 1997).

\section{Population Trends of Arctic Terns}

The numbers of nesting arctic terns declined in all regions where they were originally present in the 1980s, although the decline was significant only for the Laddie Islands. Our ability to detect significant declines was limited by the high variance associated with the number of nests per island (i.e., many islands did not have any nests on them) and the reliance of our analysis on data summarized in the 1980s. However, direct comparisons of individual islands that had supported large colonies in the 1980s showed dramatic declines. For example, in the Laddie Island region, we found only three nests on an island that had supported 78 nests in 1985 .

Tern colonies are known to move after being disturbed or displaced from their nesting areas (Morris and Hunter, 1976). Resident Inuit of the Belcher Islands collect tern eggs as a delicacy, so colonies that are easily accessible to egg-gathering parties may be abandoned after a single year or several years of reproductive failure (Forbes et al., 1992). Interestingly, the greatest declines for both gulls and terns occurred in the Laddie Islands, the region most accessible to Inuit from Sanikiluaq. If terns had moved to other islands within the Belchers, we would expect, given 
our extensive survey coverage, to have found some regions where tern numbers increased (see Methods). However, we did not find any regions within the Belcher Islands where the numbers of arctic tern nests had increased. It is possible that the terns breeding in the Belcher Islands in the 1980s emigrated to breed elsewhere. However, the Belcher Islands are isolated in Hudson Bay (the nearest island archipelago is the Nastapoka Islands, $120 \mathrm{~km}$ to the east), so the destination to which arctic terns would emigrate is not apparent.

Factors away from the breeding grounds can reduce adult survival and the population size of nesting terns. For example, roseate tern (Sterna dougallii) populations in New England are declining, and low annual survival is implicated as the cause (Spendelow et al., 1995). However, this unexplained mortality is not occurring on the breeding grounds (Spendelow et al., 1995). A similar, and as yet unidentified, source of mortality may be causing the observed decline in the numbers of nesting arctic terns in the Belcher Islands. Identifying local and global factors will be crucial in maintaining arctic tern populations in the Belcher Islands in the future.

\section{ACKNOWLEDGEMENTS}

D. Nakashima, D. Murray, Brian Fleming, and Miriam McDonald organized and summarized information from the surveys in the 1980s. Without their efforts, this comparison would not have been possible. Maureen Kay (Canadian Wildlife Service, Yellowknife), M. McDonald, and B. Fleming helped to organize the 1997 survey. Lucassie Arragutainaq and the Sanikiluaq Hunters and Trappers Association provided logistical and organizational support. We thank the survey crew: Annie Arragutainaq, Caroline Arragutainaq, Johnassie Arragutainaq, Lucassie Inuktaluk, Meena Ippak, Mina Inuktaluk, Joseph Kigilak, Noah Meeko, Moses Mickiyuk, Sarah Mickiyuk, and Alec Sala for their hard work in the field. We especially thank Paulossie Mickiyuk, who captained the Pitsiulak, and Johnassie Inuktaluk, who led the field crews. We thank Tony Gaston, Mark Hipfner, Hans Blokpoel, Sam Barry, and Mike Fournier for helpful comments on earlier drafts of this manuscript. This study was funded by the Canadian Wildlife Service and the Nunavut Wildlife Management Research Trust. This manuscript was prepared while GJR was supported by the Science Horizons Youth Internship of Environment Canada and the Atlantic Cooperative Wildlife Ecology Research Network.

\section{REFERENCES}

BLOKPOEL, H., and TESSIER, G.D. 1986. The ring-billed gull in Ontario: A review of a new problem species. Canadian Wildlife Service Occasional Paper Series 57. Ottawa: Canadian Wildlife Service. 34 p.

CHAPDELAINE, G. 1995. Fourteenth census of seabird populations in the sanctuaries of the north shore of the Gulf of St. Lawrence, 1993. Canadian Field-Naturalist 109:220-226.
COURTNEY, P.A., and BLOKPOEL, H. 1983. Distribution and numbers of common terns on the lower Great Lakes during 1900-1980: A review. Colonial Waterbirds 6:107-120.

DRURY, W.H. 1973. Population status of New England seabirds. Bird-Banding 44:267-313.

- 1974. Population status of New England seabirds. BirdBanding 45:1-12.

EWINS, P.J., BLOKPOEL, H., and LUDWIG, J.P. 1992. Recent extensions of the breeding range of great black-backed gulls, Larus marinus, in the Great Lakes of North America. Ontario Birds 10:64-71.

FLEMING, B., and McDONALD, M. 1987. A nest census and the economic potential of the Hudson Bay eider in the south Belcher Islands, N.W.T. A report prepared for the Department of Indian and Northern Affairs, GNWT Region. Project number 176057. Sanikiluaq, Northwest Territories: Municipality of Sanikiluaq. $114 \mathrm{p}$.

FORBES, G., ROBERTSON, K., OGILVIE, C., and SEDDON, L. 1992. Breeding densities, biogeography, and nest depredation of birds on Igloolik Island, N.W.T. Arctic 45:295-303.

FREEMAN, M.M.R. 1970. The birds of the Belcher Islands, N.W.T., Canada. Canadian Field-Naturalist 84:277-290.

FURNESS, R.W., ENSOR, K., and HUDSON, A.V. 1992. The use of fisheries waste by gull populations around the British Isles. Ardea 80:105-113.

GILCHRIST, H.G. 1998. Declining thick-billed murre, Uria lomvia, colonies experience higher gull predation rates: An inter-colony comparison. Biological Conservation 87:21-29.

GÖTMARK, F., and ÅHLUND, M. 1988. Nest predation and nest site selection among eiders Somateria mollissima: The influence of gulls. Ibis 130:111-123.

HANEY, J.C., and MACDONALD, S.D. 1995. Ivory gull (Pagophila ebernea). Poole, A., and Gill, F., eds. The birds of North America. No. 175. Philadelphia: The Academy of Natural Sciences; Washington, D.C.: The American Ornithologists' Union. $24 \mathrm{p}$.

HOWES, L.A., and MONTEVECCHI, W.A. 1993. Population trends and interactions among terns and gulls in Gros Morne National Park, Newfoundland. Canadian Journal of Zoology 71:1516-1520.

KISTCHINSKI, A.A., and FLINT, V.E. 1974. On the biology of the spectacled eider. Wildfowl 25:5-15.

KOMDEUR, J., BERTELSEN, J., and CRACKNELL, G. 1992. Manual for aeroplane and ship surveys of waterfowl and seabirds. Special Publication 19. Slimbridge, United Kingdom: International Waterfowl and Wetlands Research Bureau. 37 p.

KRESS, S. 1983. The use of decoys, sound recordings, and gull control for re-establishing a tern colony in Maine. Colonial Waterbirds 6:185-196.

MANNING, T.H. 1976. Birds and mammals of the Belcher, Sleeper, Ottawa, and King George Islands, N.W.T. Canadian Wildlife Service Occasional Paper No. 28. Ottawa: Canadian Wildlife Service. $40 \mathrm{p}$.

McDONALD, M., and FLEMING, B. 1990. Development of a community-based eider down industry in Sanikiluaq: Resource management and business strategies. A report prepared for the Canada-Northwest Territories Economic Development 
Agreement Project Number 561 510. Sanikiluaq, Northwest Territories: Municipality of Sanikiluaq. $60 \mathrm{p}$.

McDONALD, M., ARRAGUTAINAQ, L., and NOVALINGA, Z. 1997. Voices from the Bay: Traditional ecological knowledge of Inuit and Cree in the Hudson Bay bioregion. Ottawa: Canadian Arctic Resources Committee.

MEHLUM, F. 1991. Egg predation in a breeding colony of the common eider Somateria mollissima in Kongsfjorden, Svalbard. Norsk Polarinstitutt Skrifter 195:37-45.

MORRIS, R.D., and HUNTER, R.A. 1976. Factors influencing desertion of colony sites by common terns (Sterna hirundo). Canadian-Field Naturalist 90:137-143.

MORRIS, R.D., KIRKHAM, I.R., and CHARDINE, J.D. 1980. Management of a declining tern colony. Journal of Wildlife Managment 44:241-245.

MORRIS, R.D., BLOKPOEL, H., and TESSIER, G.D. 1992. Management efforts for the conservation of common terns Sterna hirundo colonies in the Great Lakes: Two case histories. Biological Conservation 60:7-14.

MUNRO, J., and BÉDARD, J. 1977. Gull predation and crèching behaviour in the common eider. Journal of Animal Ecology 46:799-810.

NAKASHIMA, D.J., and MURRAY, D.J. 1988. The common eider (Somateria mollissima sedentaria) of eastern Hudson Bay: A survey of nest colonies and Inuit ecological knowledge. Environmental Studies Revolving Funds Report No. 102. Ottawa. $198 \mathrm{p}$.

NISBET, I.C.T. 1973. Terns in Massachussetts: Present numbers and historical changes. Bird-Banding 44:50-58.

PIEROTTI, R., and ANNETT, C.A. 1991. Diet choice in the herring gull: Constraints imposed by reproductive and ecological factors. Ecology 72:319-328.

PIEROTTI, R., and GOOD, T.P. 1994. Herring gull (Larus argentatus). Poole, A., and Gill, F., eds. The birds of North America. No. 124. Philadelphia: The Academy of Natural Sciences; Washington, D.C.: The American Ornithologists' Union. 27 p.
PONS, J.M. 1992. Effects of changes in the availability of human refuse on breeding parameters in a herring gull(Larus argentatus) population in Britanny, France. Ardea 80:143-150.

REGEHR, H.M., and MONTEVECCHI, W.A. 1997. Interactive effects of food shortage and predation on breeding failure of black-legged kittiwakes: Indirect effects of fisheries activities and implications for indicator species. Marine Ecology Progress Series 155:249-260.

ROBERTSON, G.J., and COOKE, F. 1993. Intraclutch egg-size variation and hatching success in the common eider. Canadian Journal of Zoology 71:544-549.

ROBERTSON, G.J., and GILCHRIST, H.G. 1998. Evidence of population declines among common eiders breeding in the Belcher Islands, Northwest Territories. Arctic 51:378-385.

SCHENKEVELD, L.E., and YDENBERG, R.C. 1985. Synchronous diving by surf scoter flocks. Canadian Journal of Zoology 63:2516-2519.

SIBLY, R.M., and McCLEERY, R.H. 1983. The distribution between feeding sites of herring gulls breeding at Walney Island, U.K. Journal of Animal Ecology 52:51-68.

SPAANS, A.L. 1971. On the feeding ecology of the herring gull Larus argentatus Pont. in the northern part of the Netherlands. Ardea 65:25-42.

SPENDELOW, J.A., NICHOLS, J.D., NISBET, I.C.T., HAYS, H., CORMONS, G.D., BURGER, J., SAFINA, C., HINES, J.E., and GOCHFELD, M. 1995. Estimating annual survival and movment rates of adults within a metapopulation of roseate terns. Ecology 76:2415-2428.

STEWART-OATEN, A. 1995. Rules and judgements in statistics: Three examples. Ecology 76:2001-2009.

SWENNEN, C. 1989. Gull predation upon eider Somateria mollissima ducklings: Destruction or elimination of the unfit? Ardea 77:21-44.

ZAR, J.H. 1984. Biostatistical analysis. Toronto: Prentice-Hall. 